\title{
TERGAL AND STERNAL GLANDS IN MALE ANTS*
}

\author{
By Bert Hölldobler and Hiltrud ENGel-Siegel \\ Department of Organismic and Evolutionary Biology, \\ MCZ-Laboratories, Harvard University, \\ Cambridge, Massachusetts.
}

\section{Introduction:}

Several recent morphological investigations have uncovered a variety of hitherto unknown or neglected exocrine glandular structures in ant workers (Hölldobler and Haskins 1977; Hölldobler and Engel 1978; Kugler 1978; Jessen et al 1979; Hölldobler et al 1982; Hölldobler 1982; Jessen and Maschwitz in press). The behavioral functions of several of these glands have already been determined (For review see Hölldobler 1982).

These studies dealt almost exclusively with ant females and except for the results of Janet's (1902) classical histological investigations of the internal anatomy of males of Myrmica rubra, nothing is known about exocrine glandular structures in the gaster of ant males. Since we consider this information important not only for a further analysis of the behavior of ant males, but especially for our understanding of the evolution of pheromone glands and chemical communcation in ants, we have undertaken a histological study of exocrine glandular structures in ant males. In this paper we present a survey of the abdominal glands not directly associated with the gonads. The purpose of this paper is not to give detailed descriptions of each gland found, but rather to present a comparative account of abdominal glands detected in representative species in the different subfamilies.

\section{Materials and Methods:}

For histological investigations live specimens were fixed in alcoholic Bouin or Carnoy (Romeis 1948), embedded in methyl methacrylate, and sectioned $8 \mu$ thick with a D-profile steel knife on a Jung Tetrander I microtome (Rathmayer 1962). The staining was Azan (Heidenhain). Especially small objects were embedded in a water soluble plastic (JB-4 embedding kit, Polysciences, Inc., Pennsyl-

\footnotetext{
*Manuscript received by the editor Mav 1, 1982
} 
vania) and sectioned 4-6 $\mu$ thick with glass knives on a rotary microtome. In this case the staining was Hematoxylin-Eosin (triple strength). The SEM pictures were taken with an AMR 1000 A Scanning Electron Microscope. In a few cases only specimens were available which had been preserved in $70 \%$ ethanol.

Results:

The major results are summarized in table I. In the following we will discuss some of the details of our findings.

\section{Penis and subgenital plate glands:}

Janet (1902) described in males of the myrmicine species Myrmica rubra two major glandular structures directly associated with the copulatory apparatus. (1) The first comprise the penis glands, paired clusters of glandular cells located inside the penis valves (Fig. 1). Each cell sends a duct through a membrane into the lumen formed by the valves (sperm gutters). This gland was also detected in males of Formica rufa (Clausen 1938) in Conomyrma brunnei and Forelius sp. (Marcus 1953; cit. in Forbes 1954), in Camponotus pennsylvanicus (Forbes 1954), in Neivamyrmex harrisi (Forbes \& Do-VanQuy 1965) and we found it in representative species of all major subfamilies of ants. The size of the paired penis gland clusters (which are also called aedeagal gland, Forbes 1954) varies greatly among different species. In some it is a major gland (Fig. 1). In others it is represented only by a few glandular cells, and sometimes we were unable to identify the opening of the glandular ducts. (2) The other major gland, associated with the copulatory apparatus is located in the 9th sternite, which together with the coxopodites comprise the subgenital plate (Weber 1954). We therefore named these paired clusters of glandular cells "subgenital plate gland". Each glandular cell sends a duct through the intersegnental membrane into the ventral part of the genital chamber (Fig. 1,2). The subgenital plate gland was found in representative species of all subfamilies studied.

Tergal glands:

In his study of the workers and males of Myrmica rubra, Janet $(1898,1902)$ discovered a pair of clusters of a few glandular cells under the 6th abdominal tergite. Each cell is drained by a duct that penetrates the intersegmental membrane between the 6th and 7 th 
A
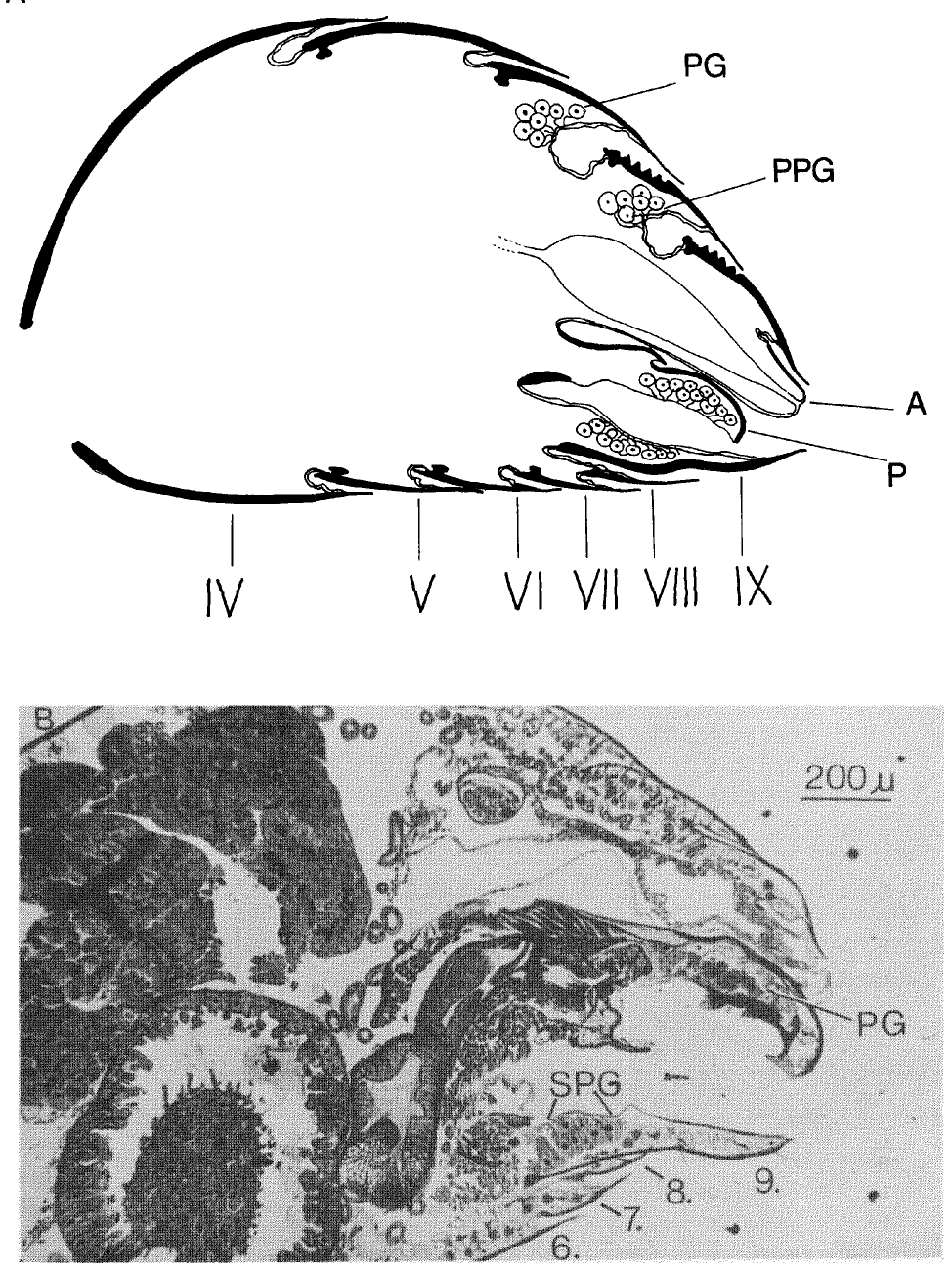

Fig. 1 A. Schematic drawing of a longitudinal section through the gaster of a Novomessor $\hat{\sigma}$. B. Longitudinal section through 6th, 7th, 8th and 9th abdominal segments of a Novomessor albisetosus $\hat{\delta}$. $\mathrm{A}=$ anus; $\mathrm{P}=$ part of penis with penis gland; $P G=$ pygidial gland; $P P G=$ post-pygidial gland; $S P G=$ subgenital plate gland. 

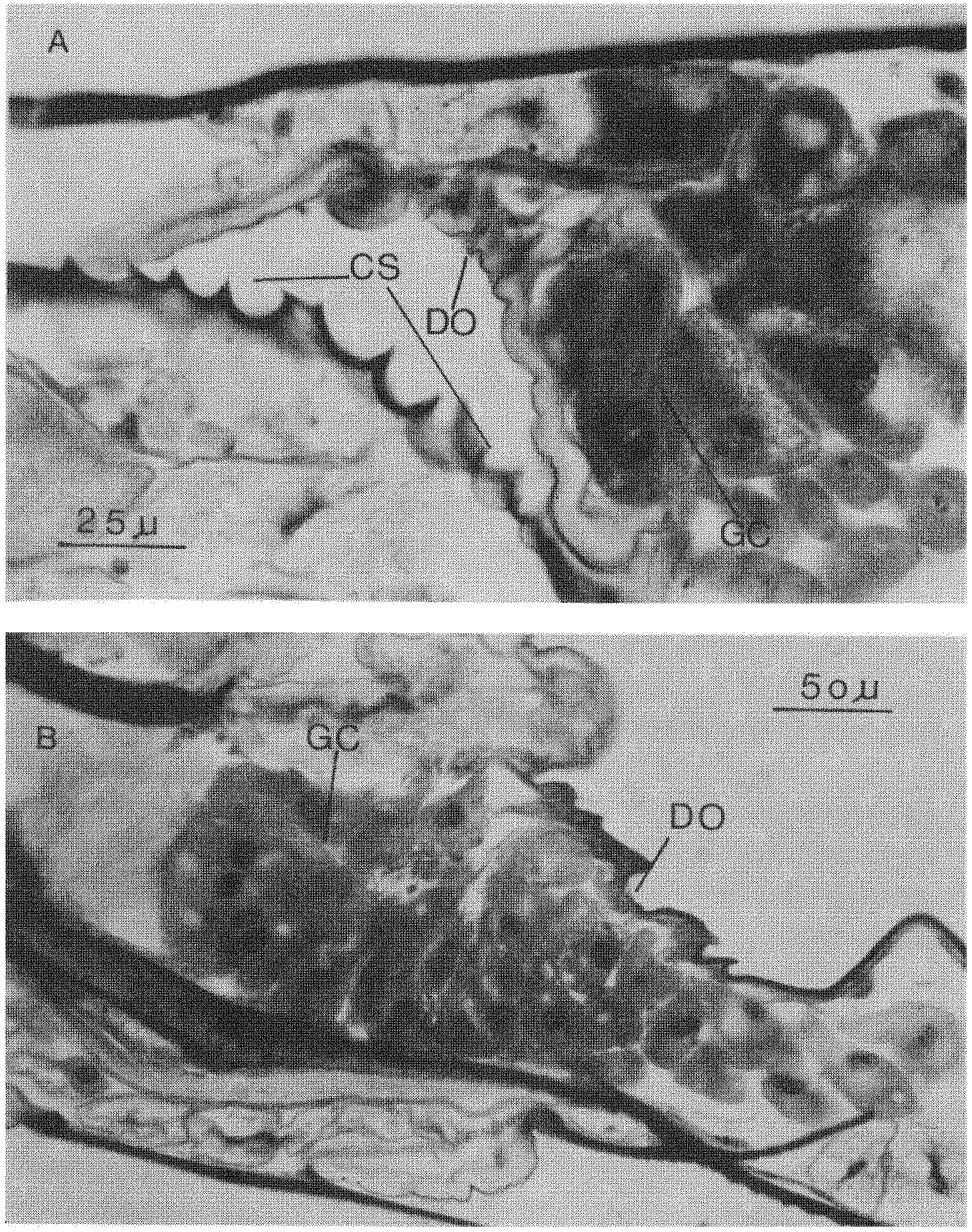

Fig. 2 A. Longitudinal section through pygidial gland of Novomessor albisetosus ¿. B. Longitudinal section through subgenital plate gland of $N$. albisetosus ô. $\mathrm{CS}=$ cuticular structure; $\mathrm{GC}=$ glandular cells; $\mathrm{DO}=$ openings of glandular ducts. 
abdominal tergites. In recent investigations this gland was found in workers of representative species belonging to all subfamilies, except in the Formicinae. Although the structure and size of the gland varies greatly, its wide distribution led us to conjecture that this gland might be a primitive monophyletic trait in ants generally, perhaps reaching back to the typhioid (or mutilloid) wasp ancestors of ants. In fact, we have recently found first indications that this gland is also present in some living typhiid wasps.

Since this gland is anatomically closely associated with the last exposed tergite in female ants ( 7 th abdominal tergite $=$ pygidium $)$ Kugler (1978) suggested that it be called the pygidial gland. Of the several tergal glands recently discovered, the pygidial gland appears to be the most frequent in occurrence. Moreover, in several species its secretions have been found to serve as pheromones (Hölldobler et al 1976; Hölldobler and Haskins 1977; Maschwitz and Schönegge 1977; Kugler 1979; Hölldobler and Traniello 1980 a,b; Traniello and Jayasuriya 1981). The pygidial gland seems to be homologous with the "anal glands" of the dolichoderine ants described by Pavan and Ronchetti (1955). As we pointed out previously (Hölldobler and Engel 1978) the term "anal gland" is misleading, because the gland does not exit from the anal or cloacal opening of the gaster, but between the 6 th and 7 th abdominal tergites. We therefore suggested to refer the dolichoderine structure to the pygidial gland. Recently Jessen and Maschwitz (in press) proposed to name the pygidial gland in honor of its discoverer Charles Janet. Thus we have now three names for this tergal gland: anal gland, pygidial gland and Janet's gland.

Because the anatomical designation of the organ in ant workers (a criterion we prefer) has been used in several recent publications, we will continue to call the tergal gland opening between the 6th and 7 th abdominal tergites pygidial gland.

Table 1. (Following pages) List of species that were investigated histologically, and of the types of tergal and sternal glands found. When the histological series was incomplete and we could not make a definite statement, or when we could not clearly identify glandular ducts, the column is marked with a "?". $r=$ with reservoir; $c=$ with cuticular structure. 
TABLE 1

Subfamily/species

MYRMECIINAE

Myrmecia pilosula

PONERINAE

Diacamma australis

Ectatomma ruidum

Ectatomma tuberculatum

Leptogen!'s diminuta

Pachycondyla apiacalis

Pachicondyla obscuricornis

Paltothyreus tarsatus

Rhıtidoponera metallica

DORYLINAE

Eciton

Neivamirmex

PSEUDOMYRMECINAE

Pseudomyrmex pallidus

MYRMICINAE

Catalacus intrudens

Leptothorax (Macromischa)

alardicei

Novomessor albisetosus

Novomessor cockerelli

Orectognathus versicolor

Pogonomyrmex barbatus

NOTHOMYRMECIINAE

Nothom!rmecia macrops

ANEURETINAE

Aneuretus simoni

DOLICHODERINAE

Iridomyrmex purpureus

Liometopum apiculatum

FORMICINAE

Formica perpilosa Myrmecocystus mendax

Oecophylla longinoda
Collector and Locality

B. Hölldobler, Brindabella Ranges, Australia

B. Hölldobler, Townsville, Qld., Australia

J. Traniello, BCl, Panama

J. Traniello, BCI, Panama

B. Hölldobler, Kuranda, Qld., Australia

J. Traniello, BCI, Panama

J. Traniello, BCI, Panama

B. Hölldobler, Shimba Hills, Kenya

B. Hölldobler, Brindabella Ranges, Australia

A. Aiello, R. Silberglied, BCI, Panama

A. Aiello, R. Silberglied, BCI, Panama

P. Ward, Texas, USA

B. Hölldobler, Shimba Hills, Kenya

B. Cole Florida Keys, USA

B. Hölldobler, Arizona, USA

B. Hölldobler, Arizona, USA

B. Hölldobler, Eungella, Queensland,

Australia

B. Hölldobler, Arizona, USA

R. W. Taylor, Eyre Peninsula, Australia

Anula Jayasuriya, Sri Lanka

B. Hölldobler, Canberra, Australia

B. Hölldobler, Arizona, USA

B. Hölldobler, Arizona, USA

B. Hölldobler, Arizona, USA

B. Hölldobler, Shimba Hills, Kenya 
Intersegmental tergal glands

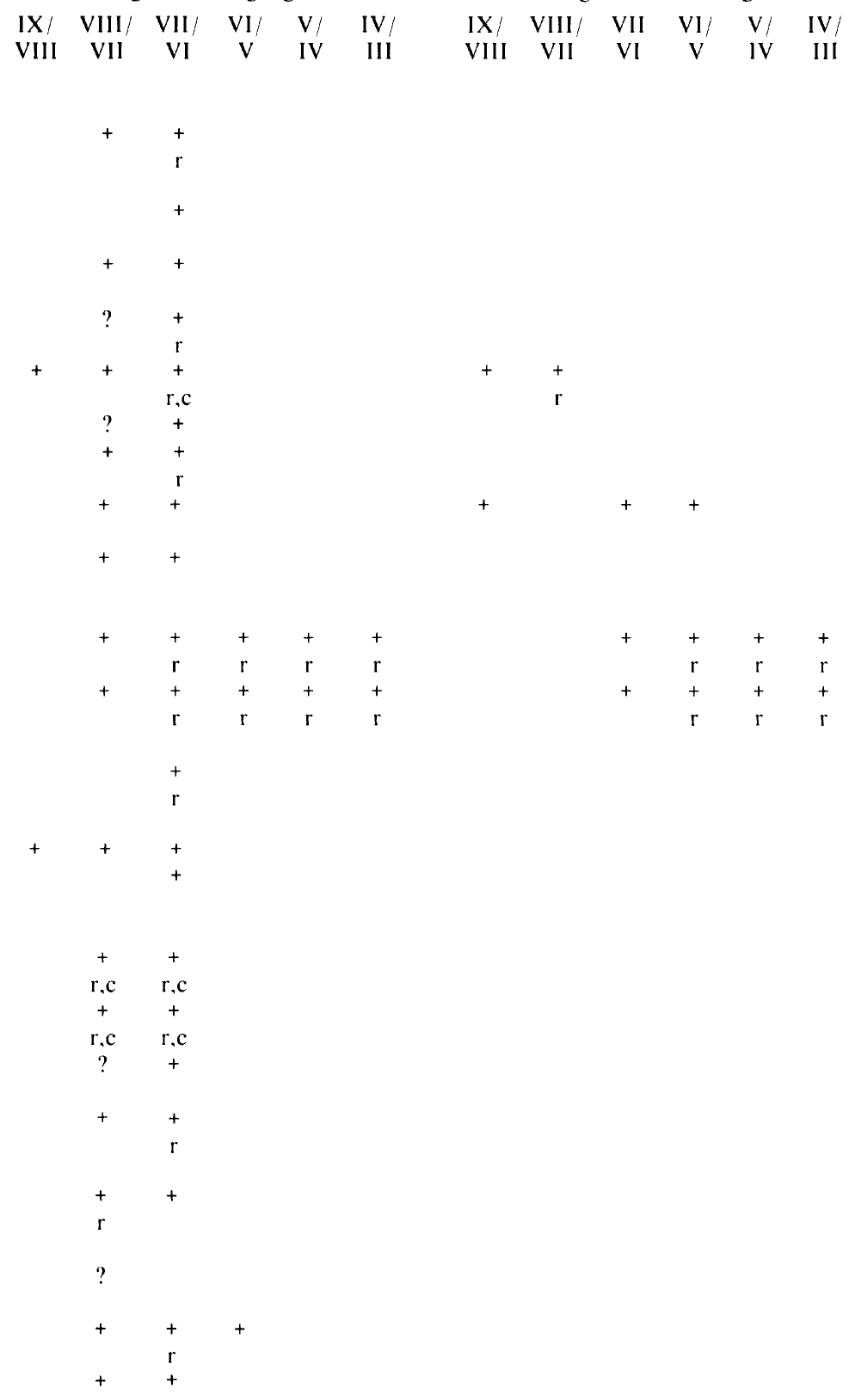


TABLE 1 (continued)

Suhfamily/species

Other tergal glands

\section{MYRMECIINAE}

Mirmecia pilosula

PONERINAE

Diacamma australis

Ectatomma ruidum

glandular cells in 7 th and 8 th segment ducts open dorsally into genital chamber

Ectatomma tuherculatum

Leptogen!s diminuta

Pachrcondry apiacalis

Pachicondila ohscuricornis

Paltothyreus tarsatus

Rhytidoponera metallica

IXth tergite; ducts open into genital chamber

\section{DORYLINAE}

Eciton

IIIrd

Neivamirme.

IIIrd

\section{PSEUDOMYRMECINAE \\ Pseudomyrmex pallidus \\ MYRMICINAE \\ Catalacus intrudens \\ Leptothorax (Macromischa) alardycei}

Nonomessor albisetosus

Noromessor cockerelli

Orectognathus versicolor

Pogonomyrmex harhatus

NOTHOMYRMECIINAE

Nothomlrmecia macrops
ANEURETINAE
Aneuretus simoni
DOI.ICHODERINAE
Iridom!rmex purpureus
liometopum apiculatum

\section{FORMICINAF. \\ Formica perpilosa \\ Mirmecocystus mendax \\ Oecophylla tonginoda}

\author{
postpetiole gland opens between IIIrd \\ tergite and postpetiole \\ postpetiole gland
}


Other sternal glands

VIIIth

glandular cells in petiole; ducts open ventrally through cuticle VIIIth

VIIIth

IIIrd VIIIth IXth

IIIrd VIIIth IXth
Sub-

genital

Tergo-sternal glands

plate

gland

Penis Anus

gland gland

Between 4/5; 5/6;
$6 / 7$ segments

Between 4/5; 5/6;

$6 / 7$ segments

Between 4/ 5;5/6;

$6 / 7$ segments

$\begin{array}{ccc}? & + & ? \\ ? & + & ? \\ \text { Between } 4 / 5 ; 5 / 6 ; & ? & ? \\ 6 / 7 ; 7 / 8 \text { segments } & & \end{array}$

$?$

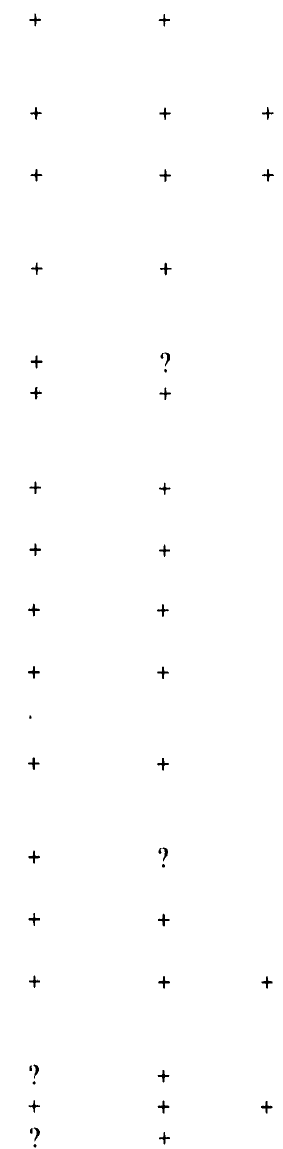


As mentioned before Janet found this gland not only in workers of $M$. rubra but also in males. Ant males differ from the workers in having one more exposed segment (8th segment); often even part of the 9 th segment is visible. Thus in ant males the pygidial gland does not open at the last exposed tergite (Fig. 1).

As can be seen from tab. 1 we found a pygidial gland in species of the subfamilies Myrmeciinae, Ponerinae, Dorylinae, Pseudomyrmecinae, Myrmicinae, Nothomyrmeciinae and Dolichoderinae. In Aneuretus simoni (Aneuretinae) we detected a few glandular cells, but we could not clearly see glandular ducts. In the males, as in the workers, there exists a considerable variation in the morphology of the pygidial glands, even within a single subfamily. In some species large clusters of glandular cells are associated with a special cuticular structure on the 7 th tergite (Fig. 1, 2, 6c). Some species possess more or less developed reservoirs, composed of an invagination of the intersegmental membrane (Fig. 3). In other species there are only a few glandular cells that send dorsolaterally ducts through the intersegmental membrane.

In ant males a post pygidial gland is almost as common as the pygidial gland (Fig. 1). It also consists of paired clusters of glandular cells that open through the intersegmental membrane, but between the 7th and 8th tergites (Tab. 1). This gland is especially well developed in Nothomyrmecia macrops males, where the intersegmental membrane forms a large reservoir. There it closely resembles the pygidial gland found in workers. Interestingly, the males of this species have only a few glandular cells between the 6th and 7 th tergites. Thus in comparison with Nothomyrmecia females (including queens) the major tergal gland in the males is shifted one segment posteriorly. In most other ant species examined, however, the gland between the 6th and 7th tergites (pygidial gland) is the major tergal gland in both workers and males.

The doryline males are a remarkable exception. They, too, have large pygidial glands, consisting of paired complex glands and a large reservoir. But the same structure is present in the next 3 segments anteriorly (6th-5th; 5th-4th; 4th-3rd) (Fig. 4, 5). In addition, intersegmental glandular cells were found between the 7 th and 8th tergites. In the 3rd tergite we also found paired groups of glandular cells, the ducts of which penetrate the sclerotized cuticle of the $3 \mathrm{rd}$ tergite dorsolaterally. 


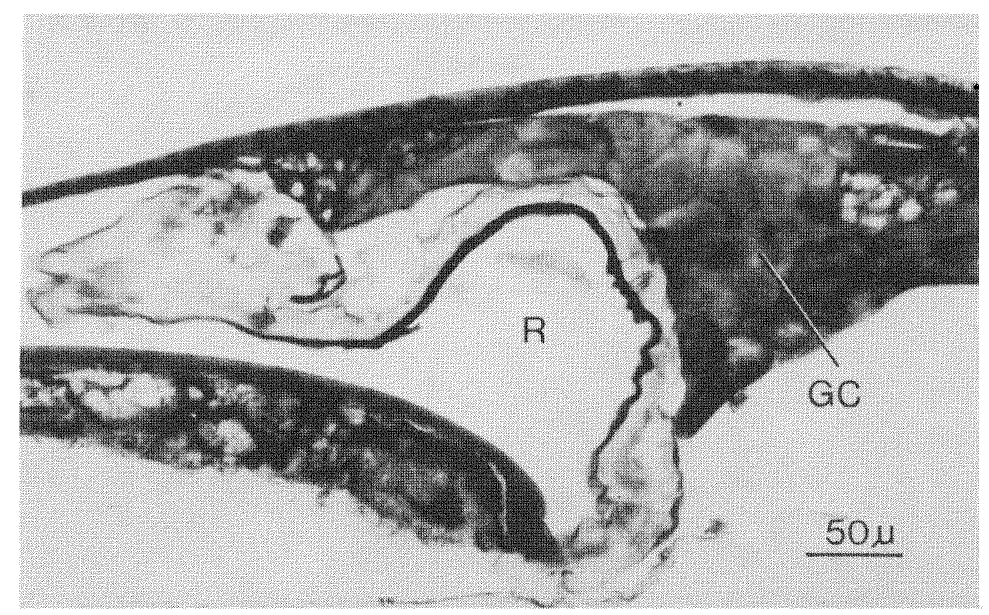

Fig. 3 Longitudinal section through pygidial gland of Pogonomyrmex barbatus §ิ. $\mathrm{GC}=$ glandular cells; $\mathrm{R}=$ reservoir.

Sternal glands:

More than in any other subfamily, the males of the doryline ants are also richly endowed with sternal glands (Tab. 1; Fig. 4). We found major complex glands with intersegmental reservoirs between the $3 \mathrm{rd}$ and $4 \mathrm{th}$, 4th and 5th, 5th and 6th sternites. Glandular clusters are also present between the 6 th and 7 th sternites-but without a pronounced reservoir. In addition, clusters of glandular cells whose ducts penetrate the sclerotized cuticle were found in the 3rd sternite, they are also strongly developed in the 8th and 9th sternites (Fig. 4). Similar sternal glands were found in the 8th sternite of males of Myrmecia pilosula, Pachycondyla apiacalis and P. obscuricornis. In both Pachycondyla species the glandular ducts open in bundles into cuticular cups located in the 8th sternite (Fig. 7a).

In the ponerine species Leptogenys diminuta the males possess a huge intersegmental sternal gland between the 7 th and 8th sternites. This gland consists of large paired clusters of glandualr cells. Each cell sends a duct into wider collecting channels which lead into a paired large reservoir, consisting of ventro-lateral invaginations of the intersegmental membrane (Fig. 6). There is a second paired sternal gland between the 8th and 9th sternite; but this gland is 

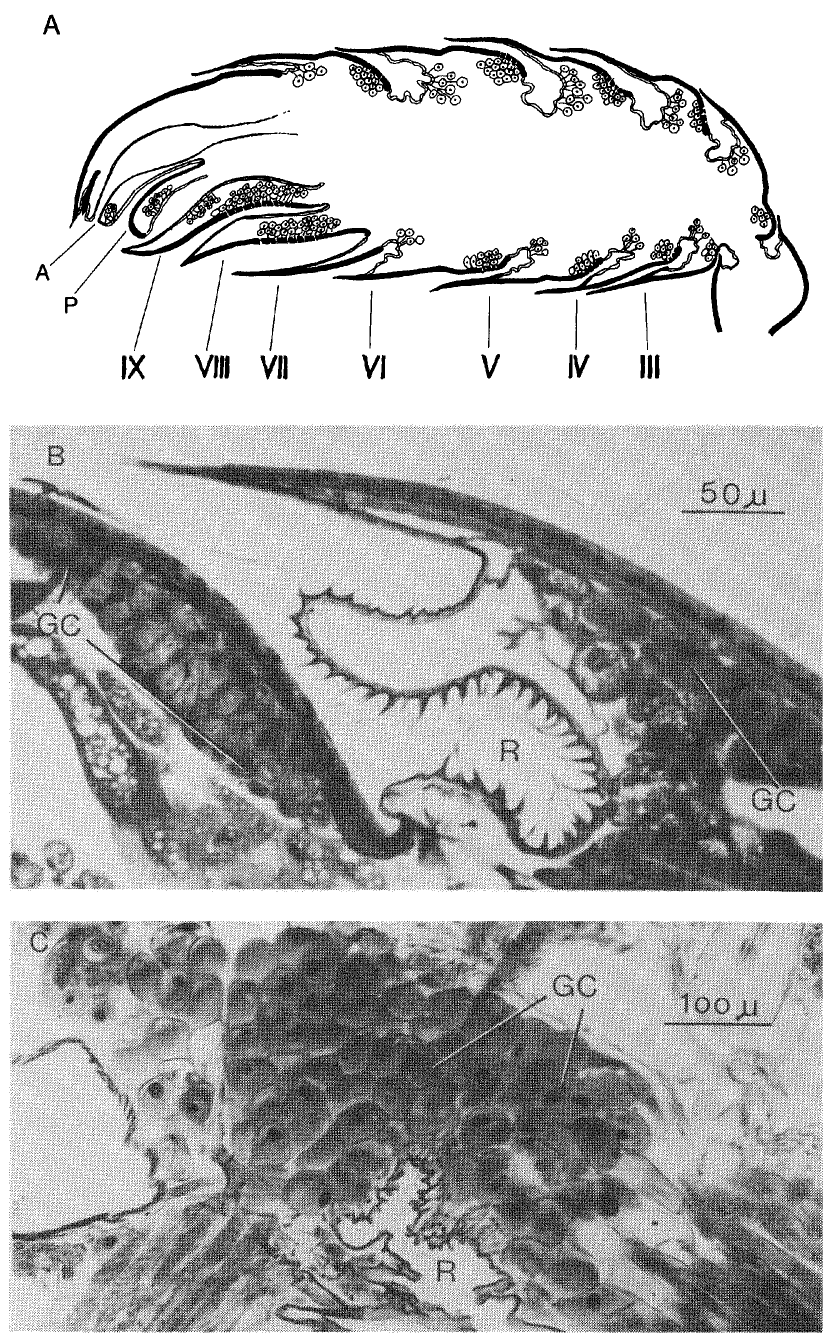

Fig. 4 A. Schematic drawing of a longitudinal section through the gaster of a Neivamyrmex spec. $\hat{\delta}$, illustrating the segmental glandular structures. B. Longitudinal section through a intersegmental complex-gland (between IVth and Vth tergites). C. Longitudinal section through a intersegmental sternal gland of Eciton spec. o. $\mathrm{A}=$ anus; $\mathrm{GC}=$ glandular cells; $\mathrm{P}=$ part of penis with penis gland; $\mathrm{R}=$ reservoir. 

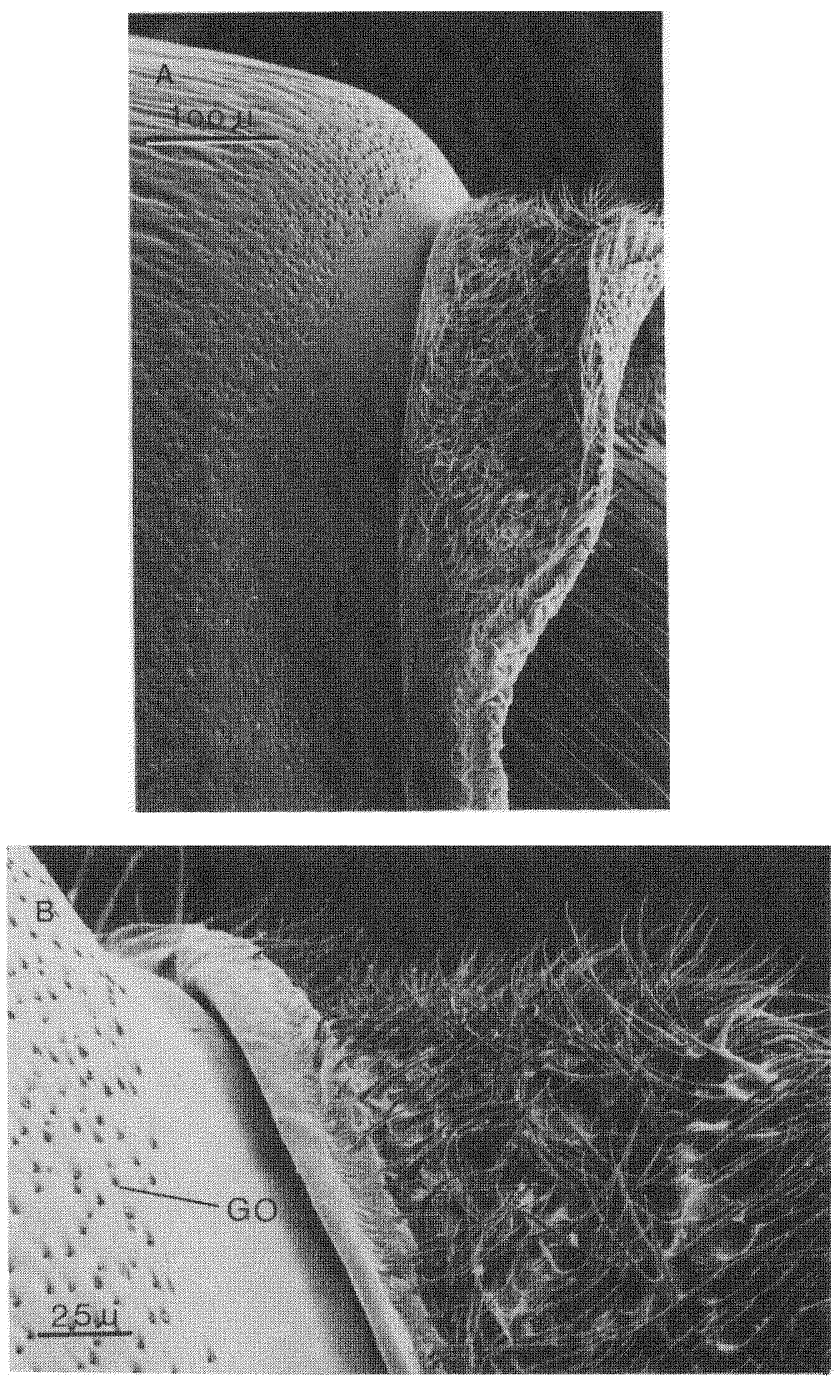

Fig. 5 A. SEM micrograph of the tergite with the attached intersegmental membrane of a Neivam!rmex $\hat{\delta}$. B. Larger magnification showing clearly the glandular duct openings in the cuticle (GO) and the intersegmental membrane which consists of a mat of bristle-like structures. This mat-membrane forms the intersegmental glandular reservoir. See also Fig. 4B. 
much smaller, and no pronounced reservoir could be detected. Leptogeny's workers have two well developed sternal glands between the 5th and 6th, and the 6th and 7th sternites respectively (Hölldobler and Engel 1978; Jessen et al 1979). Leptogeny's males lack these structures but do possess sternal glands in the 7th and 8th sternites. In males of the ponerine ant Palthothyreus tarsatus we found large paired clusters of glandular cells in the 8th sternite. The glandular ducts open through the intersegmental membrane between the 8th and 9th sternites. In addition Paltothyreus males possess unpaired intersegmental sternal glands, similar to those found in Paltothyreus workers (Hölldobler and Engel 1978), but smaller, between the 5th and 6 th, and 6 th and 7 th sternites.

Other abdominal glands:

As indicated in table 1 we found several other abdominal glands in males which cannot directly be assigned to the group of tergal or sternal glands. In a few species (Novomessor, Leptogenys) we detected glandular cell clusters in the petiole. In Ectatomma, Diacamma, Paltothyreus we found small tergo-sternal glands. The ducts of the glandular cells composing them open laterally through the pleural membrane. We found similar small glandular cell bunches in males of Pachycondyla and Rhytidoponera, but we could not clearly identify the glandular ducts. These tergo-sternal glands resemble closely similar structures described by Jessen et al (1979) in workers of several ponerine species. Finally we found small groups of glandular cells directly at the anus of males in Pachycondyla, Ectatomma, Neivamyrmex, Eciton, Myrmecocystus and Liometopum (Fig. 7b). These anus glands vary considerably in size, and it is possible that they are present in more species than we were able to document. We first found them in workers of Dorylus (Hölldobler and Engel 1978). The anus glands should not be mistaken for the rectal gland, an invagination of a glandular epithelium of the rectum, recently discovered in Oecophylla workers by Höllobler and Wilson (1978). It is interesting to note that males of Oecophylla also possess a small rectal gland.

\section{Discussion:}

Except for the glands associated with the ovipositor and sting apparatus, which the males lack, ant males are as richly endowed with exocrine glands as the females. In many species of ants the males have well developed mandibular glands, pro- and post- 

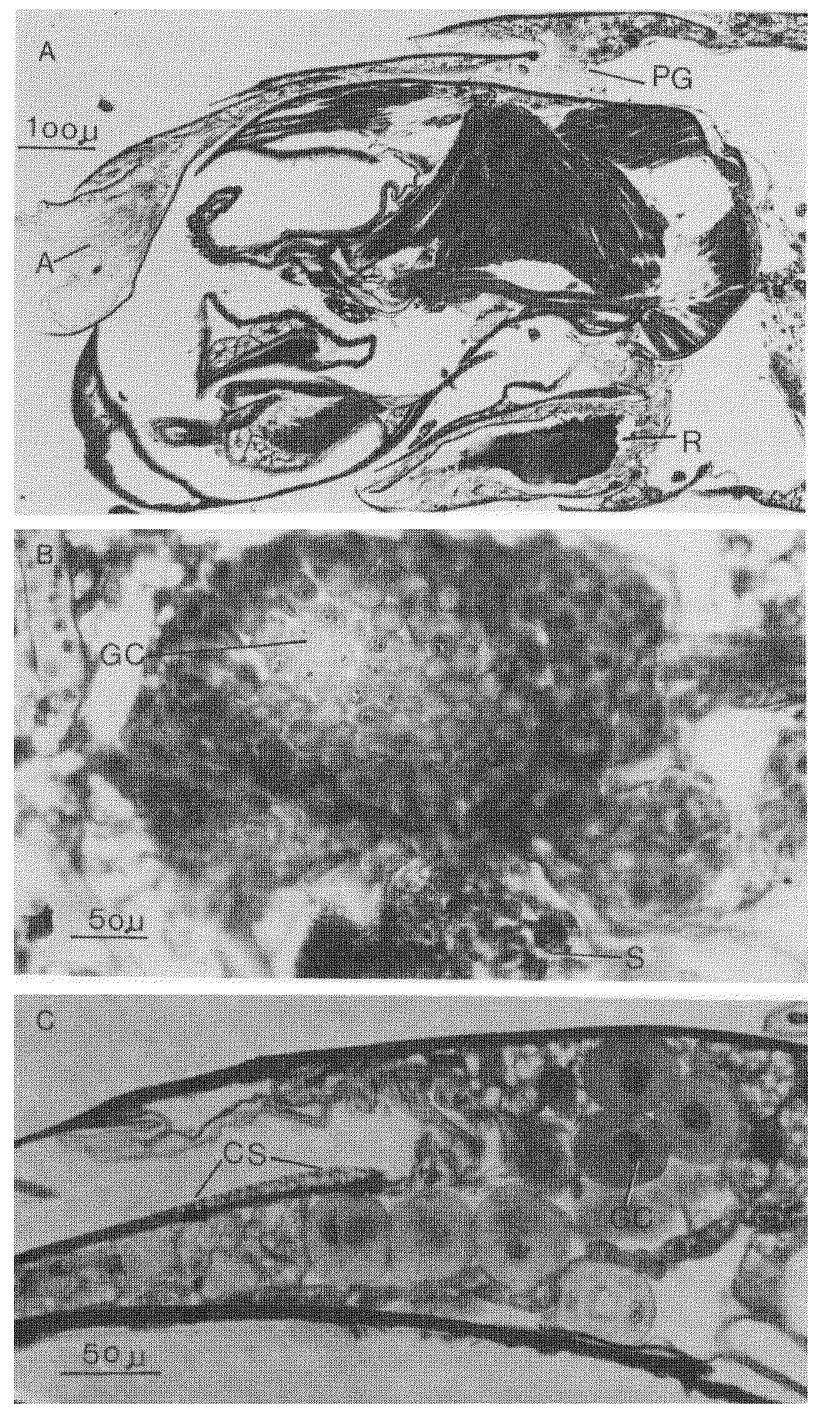

Fig. 6 A. Longitudinal section through gaster of a Leptogen!'s diminuta $\hat{0}$, showing the reservoir $(R)$ of the large sternal gland between 7 th and 8th sternites. $A=$ anus. $B$. Section through the large cluster of glandular cells of the sternal gland, opening into the reservoir between 7 th and 8 th sternite. $S=$ secretion in reservoir. C. Longitudinal section through the pygidial gland of Leptogeny's diminuta $\widehat{\delta}$. Note that the glandular cells (GC) are considerably larger than the glandular cells of the sternal gland (Fig. 6B). CS=cuticular structure 
pharyngeal glands, maxillary glands, salivary glands, and metapleural glands, although the size of these various structures can vary considerably between the female castes and males. In this paper we surveyed specifically the abdominal sternal and tergal glands in ant males.

In almost all species studied we encountered two major glandular structures that Janet (1907) had already described in Myrmica rubra, the penis glands and the subgenital plate glands. Also quite generally present in males (except in the Formicinae) are the pygidial glands. The males share these organs with the females, although less well developed in some species. An interesting case is Nothomyrmecia: here the males have a rudimentary pygidial gland but a well developed postpygidial gland (between the 7 th and 8 th tergites).

The males of the doryline ants are unusually well endowed with abdominal glands, in which they differ markedly from the workers. Although doryline workers have well developed pygidial- and postpygidial glands (Hölldobler and Engel 1978), the males have massive glandular structures in each segment. In this context the findings by Whelden (1963) are of considerable interest. Whelden described a series of exocrine glands in the gaster of Eciton queens as follows: "Each of the segments of the gaster, including those telescoped together in the posterior part, contains a pair of these glands which are smaller in the anterior segment than those in the following segments". We were not yet able to section a doryline queen and therefore cannot compare the queen organs with those we found in males. It appears, however, that the males possess a glandular equipment very similar to that of the queens. Presumably in doryline queens these massively developed exocrine glands play an important role in the queen's chemical control of the worker ants and in her high attractiveness to workers, (Watkins and Cole 1966). We hypothesize that the males imitate queen pheromones, which might enable them to penetrate a foreign colony in order to get access to the wingless virgin female reproductives (Franks and Hölldobler unpublished). In fact, this might also be the function of the massively developed sternal gland in Leptogenys males. In this genus, as in the dorylines ergatoid reproductive females presumably mate in the nest, so that males flying in from other nests have to penetrate a foreign colony. 

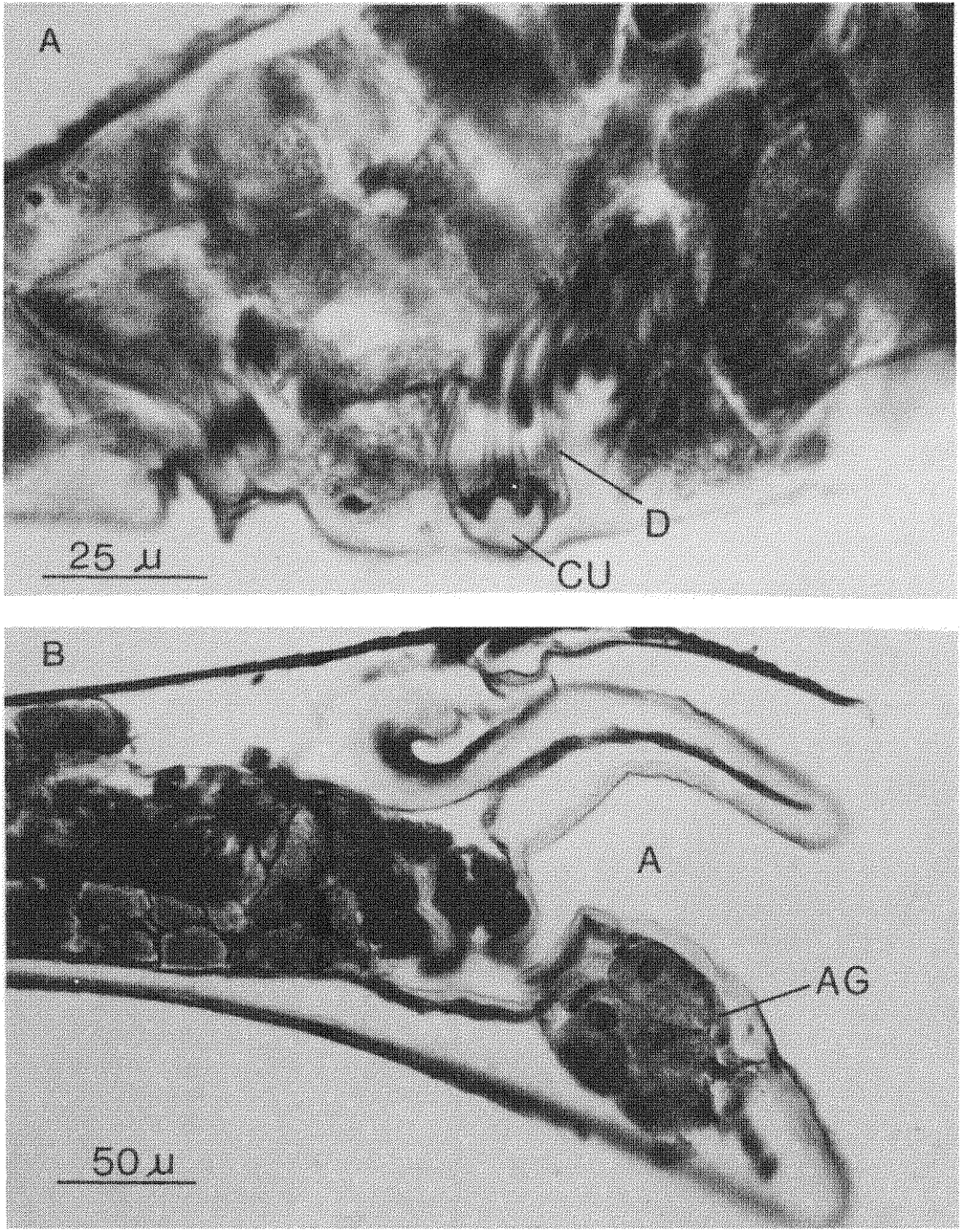

Fig. 7 A. Longitudinal section through sternal gland in 8th sternite of a Pachycondyla apiacalis $\delta . \quad \mathrm{D}=$ glandular duct; $\mathrm{CU}=$ cuticular cup. B. Longitudinal section through 8th tergite of a Ectatomma ruidum $\hat{\delta}$. $\quad \mathrm{A}=$ anus; $\mathrm{AG}=$ anus gland. 
But these are speculations. We know nothing about the function of the abdominal glands in ant males. Jessen and Maschwitz (in press) suggested that some of the numerous intersegmental glands they discovered in workers of the ponerine Pachycondyla tridentata might function as lubrication glands, reducing the friction between the segments when the workers bend the gaster during the act of stinging. In ant males some of the intersegmental glands could produce lubricants in order to keep the abdomen flexible during mating behavior or to assist the extrusion of the copulatory apparatus. On the other hand some of the well developed tergal and sternal glands seem almost certainly to produce allomones or pheromones. The recent morphological investigations of glandular structures in ants have opened a new phase in the study of chemical communication in ants.

\section{Acknowledgments:}

We would like to thank all the collectors mentioned in Table 1, and W. L. Brown, R. Snelling, R. W. Taylor for helping us with the identification of many species, and Ed Seling for his assistance during the SEM work. This work was supported by NSF grant BNS80-02613.

\section{REFERENCES}

\section{Clausen, R.}

1938 Untersuchungen über den männlichen Copulationsapparat der Ameisen, speziell der Formicinae. Mitteil. Schweiz. Entomol. Ges. 17: 1-115.

Forbes, J.

1954 The anatomy and histology of the male reproductive system in Camponotus pennsylvanicus DeGeer (Formicidae, Hymenoptera). J. Morphol. 95: 523-556.

Forbes, J. AND D. Do-VAN-QuY

1965 The anatomy and histology of the male reproductive system of the legionary ant, Neivamyrmex harrisi (Haldeman) (Hymenoptera: Formicidae). J. New York Entomol. Soc. 73: 95-111.

HÖLLDOBLER, B.

1982 The cloacal gland, a new pheromone gland in ants. Naturwissenschaften 69: 186.

1982 Chemical Communication in ants: New exocrine glands and their behavioral function. Proceeding 9th International Congress Int. Union Study of Social Insects, Boulder 1982.

HöLLDOBLER, B. AND H. ENGEL

1978 Tergal and Sternal glands in ants. Psyche 85: 285-330. 
Hölldobler, B., H. ENGel and R. W. TAYlor

1982 A new sternal gland in ants and its function in chemical communication. Naturwissenschaften 69: 90.

Hölldobler, B. ANd C. P. Haskins

1977 Sexual calling behavior in primitive ants. Science 195: 793-794.

Hölldobler, B., R. Stanton and H. Éngel

1976 A new exocrine gland in Novomessor (Hymenoptera: Formicidae) and its possible significance as a taxonomic character. Psyche 83: 32-41.

Hölldobler, B., AND J. F. A. Traniello

1980 Tandem running pheromone in ponerine ants. Naturwissenschaften 67: 360 .

Hölldobler, B., AND J. F. A. Traniello

1980 The pygidial gland and chemical recruitment communication in Pachycond!la (Termitopone) laevigata. J. Chem. Ecol. 6: 883-893.

HÖLLDOBLER, B., AND E. O. WILSON

1978 The multiple recruitment system of the African weaver ant Oecophy $/ l a$ longinoda (Latreille) (Hymenoptera: Formicidae). Behav. Ecol. Sociobiol. 3: 19-60.

JANET, CH. $_{\text {. }}$

1898 Etudes sur les Fourmis, les Guépes et les Abeilles, Note 17: Système glandulaire tégumentaire de la Myrmica rubra. Observations diverses

JANET, $\mathrm{CH}_{\text {. }}$ sur les Fourmis. Paris, Georges Carré et C. Naud, Editeurs pp. 1-30.

1902 Anatomie du gaster de la Myrmica rubra. Paris, Georges Carré et C. Naud Editeurs pp. 1-63.

Jessen, K. AND U. Maschwitz

Abdominaldrüsen bei Pachỵcondyla tridentata (Smith) (Formicidae, Ponerinae). Insectes sociaux in press.

JesSen, K., U. Maschwitz and M. Hahn

1979 Neue Abdominaldrüsen bei Ameisen 1. Ponerini (Formicidae: Ponerinae). Zoomorphologie 94: 49-66.

Kugler, $\mathrm{CH}$.

1978 Pygidial glands in myrmicine ants (Hymenoptera, Formicidae) Insectes sociaux 25: 267-274.

1979 Alarm and defense: a function for the pygidial gland of the myrmicine ant, Pheidole biconstricta. Annales Entomol. Soc. America 72: 532-536.

Marcus, $\mathrm{H}$.

1953 Estudios mirmecológicos. Folia Universitaria, Cochabamba, Bolivia 6: 17-68.

Maschwitz, U. ANd P. SCHÖNEgGE

1977 Recruitment gland of Leptogenys chinensis. Naturwissenschaften 64: 589-590.

PaVAN, M. AND G. RonchetTI

1955 Studi sulla morfologia esterna e anatomia interna dell' operaia di Iridomyrmex humilis Mayr e richerche chimiche e biologiche sulla iridomirmecina. Atti Soc, Ital. Sci. Nat. Mus. Civ. Stor. Nat. Milano 94: 379-477. 
Traniello, J. F. A. and A, K. Jayasuriya

1981 Chemical communication in the primitive ant Aneuretus simoni: The role of the sternal and pygidial gland. J. Chem. Ecol. 7: 1023-1033.

Watkins, J. F. AND T. W. Cole

1966 The attraction of army ant workers to secretions of their queens. Texas J. Sci. 18: $254-265$.

WEBER, $\mathrm{H}$.

1954 Grundriss der Insektenkunde, Gustav Fischer Verlag, Stuttgart.

WHELDEN, R. M.

1963 The anatomy of adult queen and workers of the army ants Eciton burchelli Westwood and Eciton hamatum Fabricius. New York Entomol. Soc. 71: 90-115. 

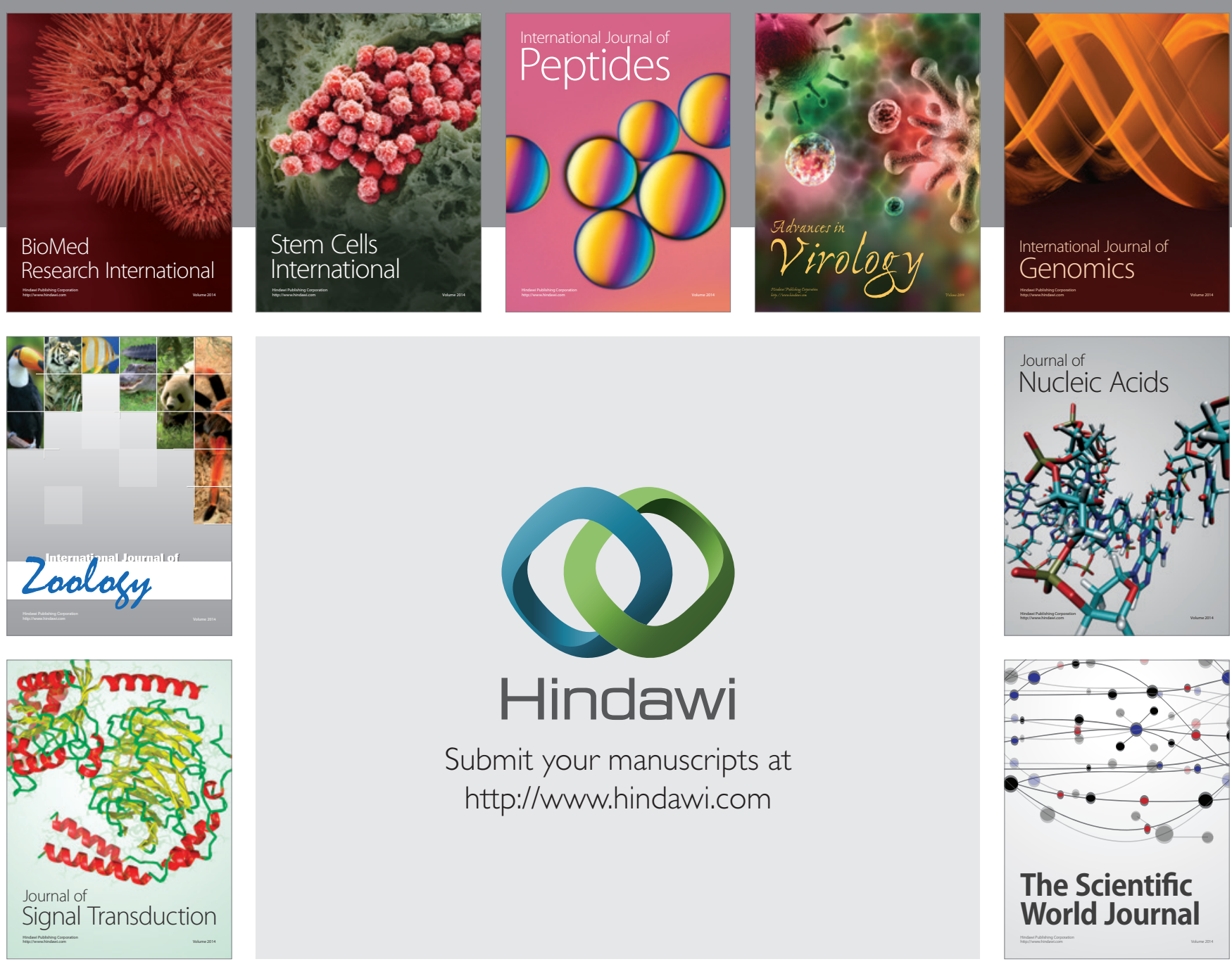

Submit your manuscripts at

http://www.hindawi.com
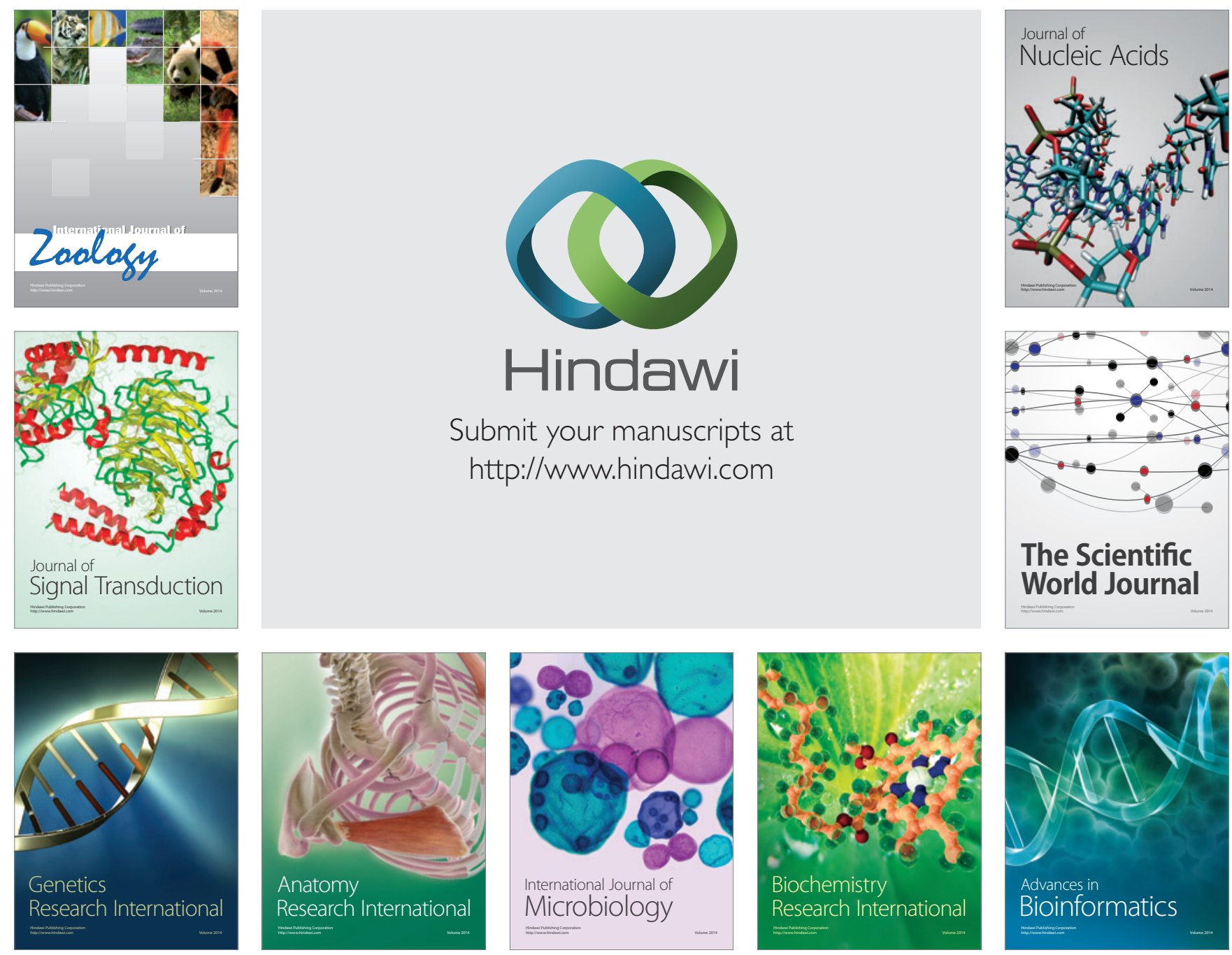

The Scientific World Journal
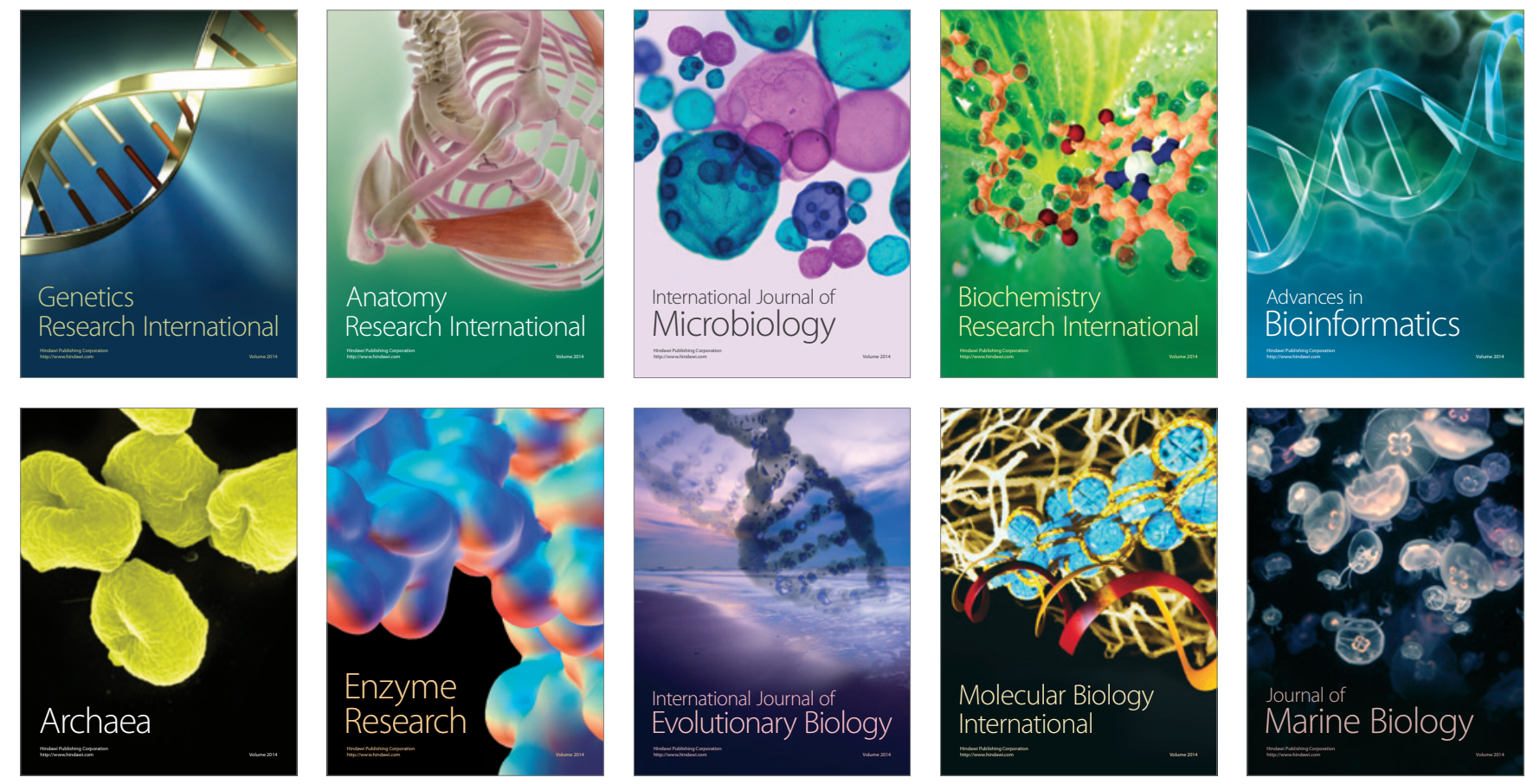